\title{
A REVIEW ON FUEL CELL AND ITS APPLICATIONS
}

\author{
Pratik Ranjan Behera ${ }^{1}$, Ritesh Dash ${ }^{2}$, S.M Ali ${ }^{3}$, Kunjan Kumar Mohapatra ${ }^{4}$ \\ ${ }^{1}$ School of Electrical Engineering, KIIT University \\ ${ }^{2}$ Ajay Binay Institute of Technology, Cuttack \\ ${ }^{3}$ School of Electrical Engineering, KIIT University \\ ${ }^{4}$ School of Electrical Engineering, KIIT University
}

\begin{abstract}
With the increase in the demand of electrical energy now it is the time to think for the alternate source of energy. In order to mitigate the demand of electrical energy and to create pollution free environment the fuel cell acts as an alternate solution. The fuel cells are very much similar to an ordinary dry cell or battery. It has an electrode, some chemical material and an electrical circuit to give the supply to an external circuit. Due to absence of rotating devices they are quite simple and efficient in nature. This paper describes about the working methods of fuel cells and their future and economic growth.
\end{abstract}

Keywords: Fuel cell, Electrolyte, Electrode, DC

$* * *$

\section{INTRODUCTION}

A fuel cell is an device that converts chemical energy into electrical energy through electrochemical conversion system till the availability of fuel. A fuel cell is known as a cell because of some similarities with a primary cell. Like conventional primary cell it also has two electrodes and an electrolyte between them and produces dc power. However, active materials are generally supplied from outside unlike a conventional cell where it is contained inside the cell. Fuel is supplied at the negative electrode, also known as fuel electrode or anode and the oxidant is supplied at positive electrode, also known as cathode. The chemical reaction takes place at the electrodes, electrolyte carries charge particles from one electrode to other and a catalyst is used to speed up the reactions at the electrodes. Both hydrogen and oxygen are the major contributor for the entire operation of an fuel cell like oxygen acts as an oxidant for the fuel cell. If hydrogen is used as fuel then water vapour is produced as exhaust. In case of hydrocarbon fuel $\mathrm{CO}_{2}$ is also produced. No other pollutants such as particulate matter, $\mathrm{NO}_{\mathrm{x}}$ and $\mathrm{SO}_{\mathrm{x}}$ are produced. A single fuel cell generates a small amount of direct current (DC) electricity. In practice, many fuel cell modules of various sizes are usually assembled into a stack as per requirement.

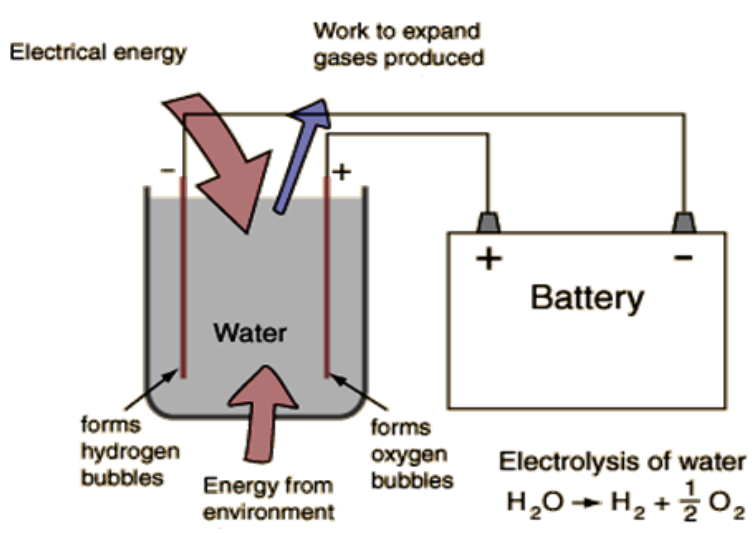

Fig:-1 Basic process of fuel cell

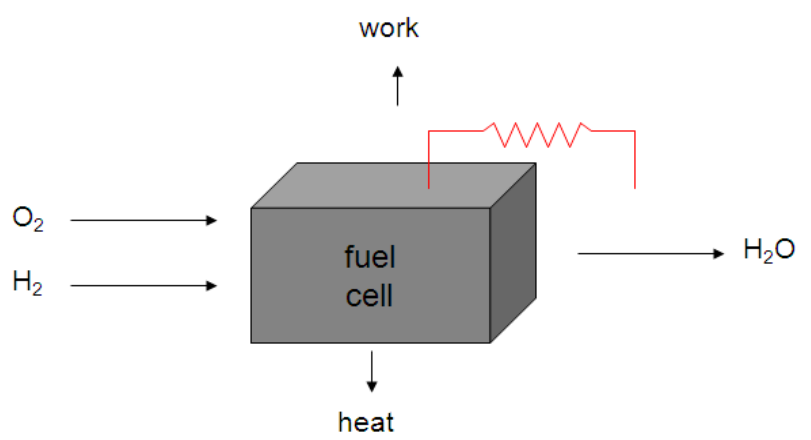

Fig-2: Operation over view.

Figure 1 and 2 shows the basic operation of fuel cell and the corresponding schematic diagram of a fuel cell. It generally takes oxygen and hydrogen to produce the electricity by releasing some amou8nt of heat as a by product. 


\section{NEED OF FUEL CELL}

As we are progressing towards being a developed nation so we are now being webbed around by technology in every bit of our life which is forcing us to use more amount of energy as compared to a decade ago. Due to recent trends of Environmental concerns like Carbon-footprint, Global Warming etc and protocols the production of energy completely by conventional means is like drawing international attention towards our own policies. So there is a need for environmental friendly, sustainable and safe energy that can provide uninterrupted power on demand basis. Some Renewable sources of energy like solar energy depend on the environment that is in an cloudy day the production of electricity is limited. Similarly in case of energy harvesting from wind also depends upon the wind speed and its direction, which cannot be controlled by us. Geothermal energy are also area specific which is not possible for good energy production. Therefore, without adequate and consistent sun, wind, heat, and water flow for hydro-electric plant such sources of power generation are nature dependent and hence are not reliable and their efficiency are also very less. On the other hand Fuel cell can act as a substitution for thermal power plant by producing less amount of pollution. With the recent advancement in the technology the fuel cell has already reached at its peak technology. With $95 \%$ power availability and electric power generation efficiency of about $50 \%$, these are the source of clean power and can be considered as the most reliable source of energy production Hydrogen is the most important parameter for the design of fuel cell hence its availability is a great concern, Direct Fuel Cells are unaffected by such limitations because they use natural gas or bio-fuels as a fuel source. Alternate source of fuel for the cell can be one of the following like ethanol and methane.

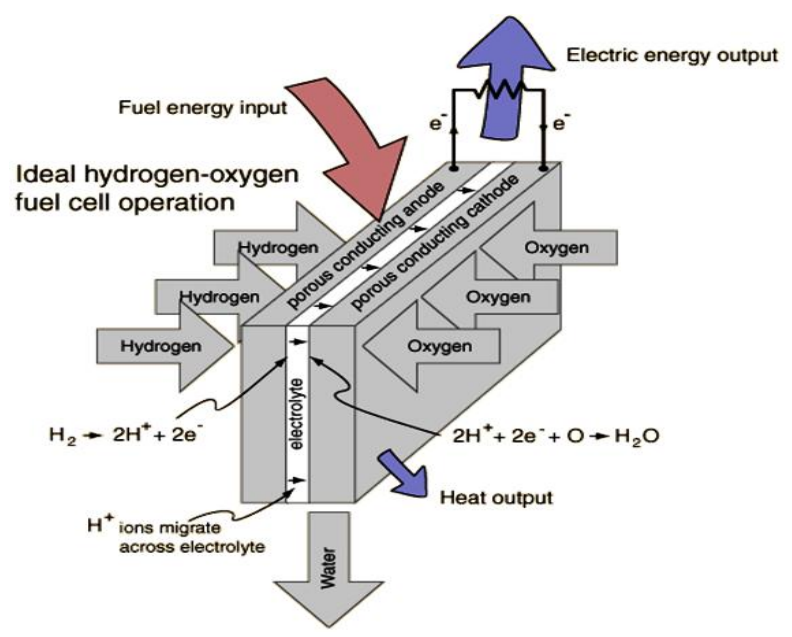

Fig:-3 Process of electricity production

Figure 3 shows the process of electricity production in a fuel cell.

\section{TYPES OF FUEL CELL}

Based on the type of Electrolyte used

\subsection{Alkaline Fuel Cells}

Alkaline fuel cells use $\mathrm{KOH}$ as electrolyte with porous electrodes of carbon having nickel or platinum as the electrocatalyst. Hydrogen is used as fuel and oxygen as oxidant. Efficiency is about 70 percent, and operating temperature is 80 to $150{ }^{\circ} \mathrm{C}$. Cell output ranges from 300 Watts to 5 Kilowatts. They require pure hydrogen fuel and their platinum electrode catalysts are expensive.

\subsection{Molten Carbonate Fuel Cells}

Molten Carbonate fuel cell needs a molten mixture of high temperature alkali carbonate like $\mathrm{Na}, \mathrm{K}$ or $\mathrm{Li}$ to be used as an electrolyte. At a nominal temperature of $600 \mathrm{oc}$ the efficiency lies in between 65 to $70 \%$. During operation they oxidize hydrogen to water and carbon monoxide to carbon dioxide. Modules with output up to $2 \mathrm{MW}$ have been constructed, and designs exist for up to $100 \mathrm{MW}$.

\subsection{Phosphoric Acid Fuel Cells}

The Phosphoric Acid Fuel cell consists of an anode of porous graphite substrate with platinum alloy as the catalyst. The cathode is similar to the anode but made with a noble-metal catalyst. The electrolyte contains concentrated phosphoric acid. It is a low temperature fuel cell and so requires high purity hydrogen. Efficiency lies in between 40 to $50 \%$ at a temperature of $150^{\circ} \mathrm{c}$. phosphoric acid cells having outputs up to $200 \mathrm{KW}$, and $11 \mathrm{MW}$ units have been tested.

\subsection{Polymer Electrolyte Membrane Fuel Cells or}

\section{Proton Exchange Membrane Fuel Cells}

A solid membrane of organic material (such as polystyrene sulphonic acid) that allows $\mathrm{H}^{+}$ions to pass through it, is used as an electrolyte. The membrane is used to keep the internal resistance of cell as low as possible. Finely divided platinum deposited on each surface of membrane serves as catalyst and current collector. Its efficiency is about 40 to $50 \%$, and operating temperature is about $40-100{ }^{\circ} \mathrm{C}$. Cell output generally ranges from 50 to $250 \mathrm{~kW}$. Low temperature operations make them suitable for automobile and home applications.

\subsection{Solid Oxide Fuel Cells}

Solid Oxide fuel cell uses a hard ceramic compound of metal (like calcium or zirconium) oxides as electrolyte. It allows iconic conductivity of oxygen ions from cathode to anode. It is a high temperature fuel cell which operates in range of 800 to $1000^{\circ} \mathrm{C}$. Output is up to $100 \mathrm{KW}$. At such a high temperature a reformer is not required to extract hydrogen from the fuel, and waste heat can be recycled to make additional electricity. 


\section{APPLICATIONS}

The three main markets for fuel cell technology are:

\subsection{Stationary Power}

- Fuel cells can be used for load leveling. When the generation exceeds the demand, excess generated energy can be converted and stored as hydrogen by electrolysis of water. During peak load time, when demand exceeds the generation, the stored hydrogen would be used in fuel cells to meet demand.

- Fuel cells are also suitable for dispersed generation. By locating the fuel cells near the load centre, transmission and distribution cost would be avoided or reduced.

- To meet the demand of isolated sites such as construction sites, military camps and small village, fuel cells are more suited than DG sets.

- Emergency or auxiliary supply to critical loads such as hospitals, educational institutions etc can be met using fuel cells.

- Combined Heat and Power: energy produced during the conversion of chemical energy to electrical energy can be extracted from the Fuels cells operating at high temperature, like Solid Oxide fuel cells and Molten carbonate fuel cells. This heat can be used to provide industrial process heat or to generate additional power employing waste heat boilers and steam turbines. It is a significant opportunity to increase the efficiency of the power plant.

\subsection{Transportation Power}

- Fuel cells can also be used as a mobile power source in vehicles, submarines and spacecrafts. A hydrogenoxygen alkali fuel cell has been used successfully to provide power in shuttle spacecrafts.

- Fuel cells are also being tested now a days as a power source for propulsion of electric vehicles like car, buses etc. In India Tata Motors and Indian space research Organization (ISRO) are conducting trials on a hydrogen powered fuel cell bus with $250 \mathrm{HP}$.

\subsection{Portable Power}

- Fuel cells can be used to power portable electronic devices, (e.g., mobile phones, laptops and other lowpower appliances, especially those used in military).

- It can be used as substitute for primary or rechargeable batteries. Instead of waiting for several hours for recharging, a small cartridge of methanol can be replaced in the way as an ink cartridge in a printer.

\section{NEW DEVELOPMENTS}

\subsection{Direct Methanol Fuel Cell}

Polymer Electrolyte Membrane Fuel cell is modified to use methanol directly without reforming, instead of pure hydrogen. The complicated catalytic reforming process is not required. Storage of methanol is much easier than hydrogen because it does not need to be done at high pressure or low temperature.

\subsection{Microbial Fuel Cell}

Here electricity is generated from human waste. Human waste contains undigested food comprising organic matter such as carbohydrates, proteins and lipids. Electrons are released because a bacterium uses the enzyme to oxidize the matter. Normally the electrons power the respiratory reactions of bacteria cells, and eventually combine with oxygen molecules. To power an external circuit the bacteria can be streamlined to one oxygen only.

Some industries has operated Phosphoric Acid Fuel Cells by using Liquefied Petroleum Gas. It has also used low grade high ash graded coal through Fluidized Bed Gasification to power Solid Oxide Fuel Cells.

Demonstration of projects are undergoing around the world, combining fuel cells with biofuels. From economic point of view thermally sensitive microbial can be employed for the extraction of energy from the biofuels. Research programs are also going on to reduce the thickness of electrolyte used in fuel cells, so as to decrease the ohmic losses in the cells.

\subsection{Future}

India suffers from huge shortage of power and lacks in rural electrification. So looking at the need to develop an alternate energy source that is capable of being stored, fuel cells are the ultimate option. But the hydrogen fuel cells are not only prohibitive in cost, are also not safe. What requires is an environmentally safe, economical source and Direct Alcohol Fuel Cell (DAFC) satisfies both these conditions. The requirement of such a product is necessitated by the market need. The use of generators, invertors and UPS is almost universal in India, in view of the undependable power supply situation, which is further worsened by its unpredictability. These appliances (generators, etc.) use diesel or lead acid batteries, the fuel cells shall make these products more dependable and environmentally savvy. Apart from this, the three wheelers in India are a prime market and if an appropriate fuel cell can be developed and marketed, that will reduce India's burden on oil import.

Recent survey has also indicated that the use of fuel cells is maximum in Asian regions and increasing year by year. 


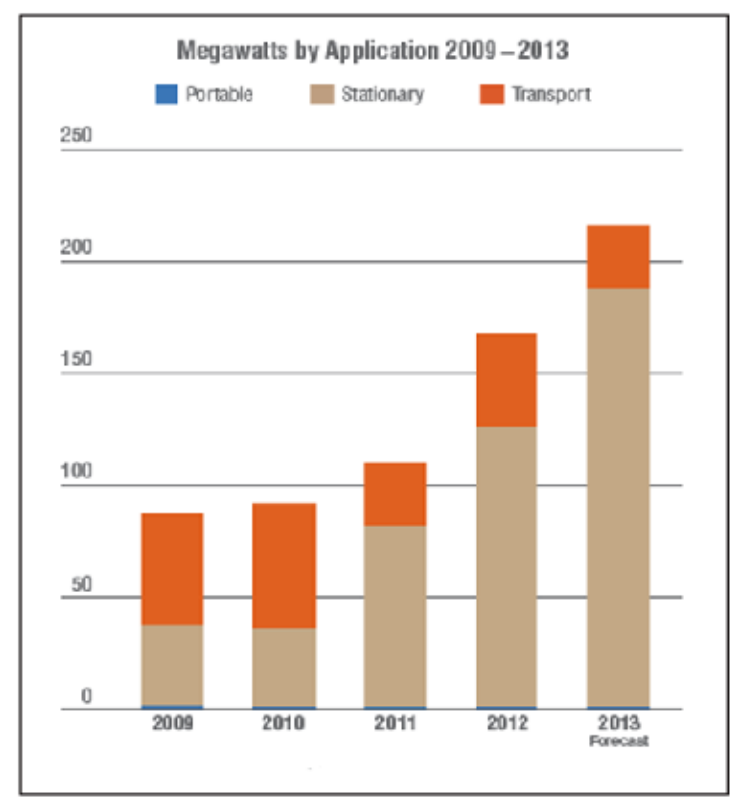

Fig:-4 use of fuel cell in different sector

Figure:-4 show the growth and use of fuel cell over time. From the figure it is clear that the main growth is in the stationary field as compared to the transport section.

\section{CONCLUSIONS}

Most of the conventional vehicles uses petroleum products as a fuel which ultimately emits the green houses and hence contributes to the global warming. However the use of fuel cell reduces the production of such green house gasses. The most and unavoidable problem about the fuel cell is the cost of product and its feasibility. Technology must be developed in order to bring the price of product to such a level where many players can play and leads to a better and sustainable environment.

\section{REFERENCES}

[1] Dincer, I. "Technical, environmental and exergetic aspects of hydrogen energy systems". International Journal of Hydrogen Energy, Vol. 27, 2002, 265-285.

[2] Dr. G. Sasikumar "Technological barriers in PEM fuel cell system development" Centre for Energy Research SPIC Science Foundation, Tamil Nadu.

[3] Rajendra N. Basu, Fuel Cell \& Battery Section" Challenges in Solid Oxide Fuel Cell Technology" Central Glass \& Ceramic Research Institute, Kolkata.

[4] IEA Advanced Fuel Cells ANNEX XIX: Stationary Fuel Cells Subtask 3: Fuels for Fuel Cells - Short Report

[5] E.A. Merewether "Alternative Sources of Energy- An Introduction to Fuel Cells"U.S. Geological Survey Bulletin 2179
[6] Ibrahim Dincer "Hydrogen and Fuel Cell Technologies for Sustainable Future", Jordan Journal of Mechanical and Industrial Engineering, Volume 2, Number 1, Mar. 2008 ,pp 1-14

[7] Midilli, A., Ay, M., Dincer, I. and Rosen, M.A. (2005b). "On hydrogen and hydrogen energy strategies-II: future projections affecting global stability and unrest", Renewable and Sustainable Energy Reviews, Vol. 9, No.3, 2005, 309- 323

[8] M. Balla, M. Wietschelb. "The future of hydrogen opportunities and challenges". International journal of hydrogen energy 34 (2009) 615-627

[9] G. Luna-Sandoval, G. Urriolagoitia-C, L.H. Hernández, G. Urriolagoitia-S, E. Jiménez" Hydrogen Fuel Cell Design and Manufacturing Process Used for Public Transportation in Mexico City", Proceedings of the World Congress on Engineering 2011 Vol III, , July 6 8, 2011, London, U.K.

[10] Reuel Shinnar," The hydrogen economy,fuel cells,and electric cars" ,Elsevier Technology in Society 25 (2003) 455-476 .

[11] W. Schmittinger and A. Vahidi, "A review of the main parameters influencing performance and durability of PEM fuel cells," Journal of Power Sources, vol. 180, pp. 1-14, 2008

[12] http://www.eere.energy.gov/hydrogenandfuelcells/pdfs/ $28890 \mathrm{~mm} . \mathrm{pdf}$

[13] W. Schmittinger and A. Vahidi, "A review of the main parameters influencing performance and durability of PEM fuel cells," Journal of Power Sources, vol. 180, pp. 1-14, 2008

[14] Balat M. Potential importance of hydrogen as a future solution to environmental and transportation problems. International Journal of Hydrogen Energy 2008, 33, 4013- 4029

[15] Mario Valentino Romeri," Hydrogen Fuel Cell Powertrain Levelized Cost Of Electricity", 30th USAEE/IAEE North American Conference, Washington DC, October 2011 